\title{
ВИВЧЕННЯ ДИСЦИПЛІНИ “ОРГАНІЗАЦІЯ ТА ЕКОНОМІКА ФАРМАЦІї” СТУДЕНТАМИ СПЕЦІАЛЬНОСТІ “ФАРМАЦІЯ”
}

А. Л. Штробля

\author{
ДВНЗ “Ужсгородський національний університет”
}

\section{STUDING OF DISCIPLINE “ORGANIZATION AND ECONOMICS OF PHARMACY" BY STUDENTS OF SPECIALITY "PHARMACY"}

\author{
A. L. Stroblia
}

\author{
SHEI "Uzhhorod National University"
}

\begin{abstract}
Дисципліна “Організація та економіка фармації” є однією з основних у підготовці фахівців зі спеціальності “Фармація”. Управлінсько-економічна підготовка майбутніх провізорів відноситься до одного з найважливіших завдань, ефективне вирішення яких забезпечує активний розвиток фармацевтичної галузі як складової частини системи охорони здоров'я. Актуальність такої підготовки зумовлена ітенсифікацією економічної та, особливо, підприємницької діяльності фармацевтичних організацій в умовах ринкових відносин.
\end{abstract}

Discipline "Organization and economics of pharmacy" is a key in training in the speciality "pharmacy". Managerial training of future economic pharmacists refers to one of the most important tasks, effective solution which provides active development of the pharmaceutical industry as part of the health care system. The relevance of such training due intensyfikation economic, and especially, business organizations in the pharmaceutical market conditions.

Вступ. Нинішній етап розвитку вищої фармацевтичної освіти характеризується системними змінами, що зумовлені:

- динамічними змінами у вітчизняній охороні здоров'я та соціальними, економічними, етичними, правовими особливостями діяльності суб'єктів системи охорони здоров'я в Україні;

- сучасними вимогами до рівня якості у галузі вищої освіти;

- створенням нових форм навчального середовища, безперервного професійного розвитку провізорів, починаючи від засобів дистанційної освіти і закінчуючи повноцінними “віртуальними програмами", освітніми комплексами.

Сучасні професійно-кваліфікаційні вимоги до економічної підготовки провізорів та інших спеціалістів фармацевтичної галузі досить високі у зв' язку з процесами глобалізації, трансформації, інтеграції та реформування сучасної фармації, i тому повинні передбачати впровадження ефективних освітніх технологій та охоплювати викладання як основу методології ринкової економіки, а також прикладних питань економіки фармації [2].

(C) А. Л. Штробля
У XXI столітті не тільки змінились пріоритети в розвитку фармації як частини галузі охорони здоров'я. Змінилась термінологія, сутність об'єкта та предмета дисципліни. В умовах планової економіки змінилась назва дисципліни “Організація фармацевтичної справи” на “Організація та економіка фармації”, залежно від пріоритетних моделей господарювання аптечних закладів - бюджетного фінансування або госпрозрахунку [3,4].

Мета - дати студентам системні знання про організаційно-економічні аспекти фармацевтичної діяльності у сучасних умовах; сприяти формуванню професійно необхідних знань, умінь та навичок; забезпечити теоретичну базу для подальшого вивчення інших фармацевтичних та економічних дисциплін навчального плану.

Основна частина. Серед основних пріоритетів освітньої діяльності важливою $є$ модернізація вищої освіти відповідно до положень Болонської декларації, орієнтація на кінцевий результат - підготовку висококваліфікованих випускників.

Впровадження болонських ініціатив здійснюється згідно з відповідними наказами МОН та МОЗ України, для реалізації яких було прийнято низку заходів у підготовці кадрів: 
- розроблені навчальні плани, адаптовані до кредитно-модульної системи організації навчального процесу;

- впроваджено індивідуальний навчальний план студента;

- оцінювання навчальних досягнень студентів здійснюється за модульно-рейтинговою системою; - відповідне навчально-методичне забезпечення.

Студенти вивчають дисципліну “Організація та економіка фармації” згідно з програмою для вищих фармацевтичних закладів України III-IV рівнів акредитації, яка складена для спеціальності 7.110201 “Фармація" відповідно до освітньо-кваліфікаційної характеристики й освітньо-професійної програми та навчального плану підготовки фахівців освітньокваліфікаційного рівня “спеціаліст" у вищих навчальних закладах IV рівня акредитації за спеціальністю "Фармація", затвердженого наказом MO3 України від $\quad 07.12 .2009$ р. № 930 .

Дисципліна "Організація та економіка фармації” вивчається студентами в VII-VIII семестрах. Як навчальна дисципліна “Організація та економіка фармації” базується на вивченні студентами економічної теорії, історії фармації, аптечної технології ліків, фармацевтичної хімії, інформаційних технологій у фармації, етики та деонтології у фармації. В той же час дана дисципліна закладає основи для вивчення студентами таких дисциплін, як "Менеджмент та маркетинг у фармації”, "Медичне та фармацевтичне товарознавство”, “Фармацевтичне законодавство”, “Фармекономіка”, що передбачає інтеграцію викладання $з$ цими дисциплінами та формування умінь застосовувати знання з ОЕФ у процесі подальшого навчання й у професійній діяльності. Організація навчального процесу здійснюється за кредитномодульною системою відповідно до вимог Болонського процесу $[1,5]$.

Програму дисципліни “Організація та економіка фармації” поділено на три модулі: модуль 1 - це організація фармацевтичного забезпечення населення, який складається 3 двох змістових модулів, а саме: організаційні принципи фармацевтичного забезпечення та організація відпуску готових лікарських засобів з аптек; модуль 2 - організація фармацевтичного забезпечення лікарськими засобами індивідуального виготовлення, контроль якості та оптова торгівля лікарськими засобами, який також має два змістових модулі: організація роботи аптек із забезпечення населення лікарськими засобами індивідуального виготовлення та організація фармацевтич- ного забезпечення лікувально-профілактичних закладів, внутрішньоаптечний контроль якості лікарських засобів, оптова торгівля лікарськими засобами; модуль 3 - облік, фінансова звітність та економічний аналіз діяльності аптек, що містить три змістових модулі: облік товарних та розрахункових операцій в аптеках, основи бухгалтерського обліку, облік фінансових результатів діяльності аптек, сучасні методи економічного аналізу фінансово-господарської діяльності аптек.

При опрацьовуванні теми “Організаційна структура управління фармацевтичною системою" студенти вивчають принципи організації фармацевтичного забезпечення населення згідно з вимогами Належної аптечної практики.

На лекціях та практичних заняттях з ОЕФ студентами спеціальності “Фармація” увага приділяється вивченню діяльності міжнародних організацій, що регулюють фармацевтичну діяльність на макроекономічному рівні (Всесвітня організація охорони здоров'я - ВООЗ; Міжнародна фармацевтична федерація -МФФ; Всесвітня торгова організація - ВТО; Європейське співтовариство - СС), значенню діяльності міжнародних організацій у розробці програм гармонізації законодавчої бази, організаційних принципів, систем управління фармації різних країн світу.

При вивченні змістового модуля 2 "Організація відпуску готових лікарських засобів з аптек” перед студентами стоять наступні завдання:

- засвоїти порядок відпуску лікарських засобів 3 аптек;

- опанувати основні критерії безрецептурного відпуску лікарських засобів;

- опрацювати алгоритми фармацевтичної опіки при відпуску безрецептурних препаратів;

- вивчити особливості рецептурного відпуску лікарських засобів;

- навчитись здійснювати приймання рецептів та відпуск лікарських засобів;

- опрацьовувати особливості пільгового та безкоштовного відпуску лікарських засобів;

- навчитись класифікувати наркотичні, психотропні речовини та прекурсори;

- вивчити особливості виписування рецептів та відпуску з аптек наркотичних, психотропних лікарських засобів та прекурсорів;

- організовувати предметно-кількісний облік лікарських засобів.

Під час вивчення дисципліни розглядаються теоретичні основи фармацевтичного ціноутворення, 
особливості державного та ринкового підходів до ціни на лікарські засоби, визначення роздрібних цін на готові ліки.

Особлива увага приділяється організації роботи аптеки з приймання рецептів та відпуску лікарських засобів, виписування та відпуску окремих груп ліків і організації предметно-кількісного обліку в аптеках.

Специфікою ОЕФ є те, що основний матеріал дисципліни грунтується на нормативно-правових документах, які регулюють діяльність фармацевтичних підприємств. При цьому варто зазначити, що науково-технічна документація надзвичайно часто змінювалась останніми роками.

Модуль 3 - “Облік товарних та розрахункових операцій в аптеках. Основи бухгалтерського обліку”. Вивчаючи цей розділ, студенти повинні вміти :

- здійснювати документальне оформлення надходження товарів;

- пояснювати економічне значення та структуру товарообороту;

- оформляти документи з обліку реалізації товарів, інших витрат товару;

- трактувати принципи обліку основних засобів та нематеріальних активів аптек;

- організовувати облік основних засобів та їх амортизаціі;

- застосовувати РРО у розрахунках зі споживачами;

- відображати господарські операції з руху готівкових коштів у документах управлінського та бухгалтерського обліку;

- знати організацію системи внутрішньогосподарського та бухгалтерського обліку в аптеках;

- трактувати основні принципи облікової політики аптечних (фармацевтичних) підприємств;

- застосовувати Положення (стандарти) бухгалтерського обліку та інші законодавчі та нормативноправові документи, що регламентують організацію обліку та звітності в Україні;

- складати баланс аптеки, пояснювати зміни в балансі;

- опрацьовувати основні положення щодо нарахування та оподаткування заробітної плати працівників аптек;

- класифікувати поняття доходів, витрат та фінансового результату діяльності аптек;

- засвоїти основні підходи до оподаткування результатів діяльності аптек;

- пояснювати особливості звітності при звичайній та спрощеній системах оподаткування.
Під час викладання дисципліни звертається істотна увага на методологію системного ведення різних видів обліку та звітності на фармацевтичному підприємстві (внутрішньогосподарський (управлінський), бухгалтерський, фінансовий, статистичний та податковий облік, облік господарських операцій руху товарів та інших товарно-матеріальних цінностей, доходів та витрат).

На практичних заняттях з ОЕФ передбачено оформлення студентами організаційної та облікової документації, здійснення економічних розрахунків та аналізу, вирішення ситуаційних задач і тестових завдань, моделювання ситуацій, які відповідають практичній діяльності фармацевтичного фахівця. Під час проведення занять систематично обговорюються найбільш важливі питання функціонування фармацевтичних підприємств в умовах глобалізації суспільства, стрімкого розвитку ринкових відносин та реформування вітчизняної фармацевтичної галузі з метою наближення їі до європейського і світового рівнів.

Особливої уваги заслуговує практична підготовка студентів, що грунтується на підвищенні мотивації до оволодіння знаннями, розвитку самоорганізації, формування професійних навичок та закріплення знань, отриманих на теоретичних заняттях. Організація та проведення практики регламентується наказом МОН від 8.04.1993 р. № 93 “Про затвердження Положення про проведення практики студентів вищих навчальних закладів України". На 5-му курсі студенти проходять виробничу практику з ОЕФ, під час якої закріплюють та розширюють теоретичні знання та набувають практичних навичок з організації роботи, виробничої, адміністративної та фінансової діяльності аптек; оволодівають сучасними принципами фармацевтичного підприємства, фармацевтичної етики і деонтології.

Для реалізації чіткої організації всіх видів практичного навчання та створення студентам умов для професійної самореалізації особистості підготовлені методичні рекомендації до практичних занять з ОЕФ та проходження всіх видів практики. Виробничу практику студенти проходять на базах міських та обласних аптечних закладів. Методичний керівник постійно підтримує тісний зв'язок зі студентами на базах практик і здійснює контроль за порядком проходження практики.

Висновки. Реформи, які переживає фармацевтична освіта, пов' язані зі змінами в системі охорони здоров'я та фармацевтичному секторі щодо надання 
якісної фармацевтичної послуги. Інноваційна діяльність освітян спрямована на пошук і відбір форм, методів і технологій навчання, що забезпечують підготовку кваліфікованих і компетентних спеціалістів.

\section{Списоклітератури}

1. Бойко А. Проблеми розвитку української освіти в умовах Євроінтеграції / А. Бойко // Вища освіта України. 2009. - №2. - С. 44-49.

2. Громовик Б. П. Компетентнісний підхід до творчої підготовки майбутніх провізорів / Б. П. Громовик, А. В. Горілик // Управління, економіка та забезпечення якості в фармації. - 2011. - № 1(5). - С. 24-29.

3. Немченко А. С. Організаційно-економічна освіта та наука: історія, тенденції, проблеми / А. С. Немченко, Г. П. Панфілова, А. А. Котвіцька [та ін.] // Пріоритети організаційно-економічної науки та освіти у розвитку вітчизняної фармації : матеріали наук.-практ. конф. - Харків : Вид-во НФаУ, 2005. - С. 3-10.
Організація та економіка фармації є важливою фармацевтичною дисципліною, яка постійно і динамічно розвивається та надалі повинна розвиватися поступово і безперервно, що дозволяє підготувати компетентного фармацевтичного працівника, який володіє професійними знаннями.

4. Парновский Б. Л. Развитие и специализация фармацевтической науки на примере организации и экономики фармации / Б. Л. Парновский, О. Н. Залиская // Провизор. -2005. -№ 1. - С. 8-10.

5. Толочко В. П. Змістові аспекти організаційно-економічних дисциплін на етапі реформування фармацевтичної освіти у світлі вимог Болонської декларації / В. П. Толочко, Л. Т. Кайдалова // Пріоритети організаційно-економічної науки та освіти у розвитку вітчизняної фармації : матеріали наук.-практ. конф. - Харків : Вид-во НФаУ, 2005. - С. 62.

Отримано 10.02.15 